\title{
IDENTIFIKASI PENYAKIT DIABETES MELLIUS MELALUI NAFAS BERBASIS SENSOR GAS DENGAN METODE FAST FOURIER TRANSFORM DAN BACKPROPAGATION
}

\author{
Mohammad Hafiz Hersyah ${ }^{1}$, Andrizal ${ }^{2}$, Revinessia ${ }^{3}$ \\ ${ }^{1,3}$ Jurusan Sistem Komputer FTI, UNAND, Jalan Kampus Limau Manis Padang, 25162, Indonesia \\ ${ }^{2}$ Politeknik Padang, Jalan Kampus Limau Manis Padang 25162, Indonesia
}

\begin{tabular}{l} 
ARTICLE INFORMATION \\
\hline Received: May 09, 2018 \\
Revised: September 12, 2018 \\
Available online: September 29, 2018 \\
KEYWORDS
\end{tabular}

Sensor Gas, Hidrogen Sulfida, Methane,

Jaringan Syaraf Tiruan, Backpropagation

CORRESPONDENCE

E-mail: mhafiz@ fti.unand.ac.id

\section{A B S T T R A C T}

\begin{abstract}
The purpose of this research is to detect whether a person has diabetes mellitus or not. In people with diabetes mellitus uncontrolled will result in a decline in the rate of saliva that results in bad breath. The system uses the sensor TGS 2602 and MQ 4. It's function is to detect the levels of Hydrogen Sulfide and Methan in a person's breath. The decision is made by using the neural network with a backpropagation method. The result for 5 (five) tests of diabetes mellitus samples can be detected with a success rate of $80 \%$, whereas using random samples, the test detected with detected with a success rate of $80 \%$ samples that didn't contain diabetes mellitus. This system could provide a solution for testing if a person is suffering from diabetes mellitus.
\end{abstract}

\section{PENDAHULUAN}

Diabetes Melitus (DM) adalah sebuah keadaan abnormal dimana produksi insulin dalam tubuh tidak mencukupi untuk mengubah glukosa yang dihasilkan karbohidrat ke dalam bentuk glikogen. Glukosa tidak dapat digunakan secara langsung oleh tubuh [1]. Diabetes yang tidak terkontrol menyebabkan penurunan saliva (air liur) sehingga mulut terasa kering. Saliva memiliki kemampuan self-cleansing, di mana alirannya berfungsi sebagai pembilas sisa sisa makanan dan kotoran dari dalam mulut. Salah satu akibat dari ini adalah terjadinya Halitosis. Halitosis disebabkan oleh terbentuknya Volatile Sulfur Compond (VSC), yang terbentuk dari kumpulan gas gas yang mengandung sulfur yang dilepaskan melalui nafas. VSC terdiri dari hydrogen sulfide $(\mathrm{H} 2 \mathrm{~S})$, methane thiol, or methyl mercaptan $(\mathrm{CH} 3 \mathrm{SH})$ dan dimethylsulfide (CH3SCH3) [2].

Pengecekan halitosis dapat dilakukan dengan menghitung kadar Volatile Sulfur Compounds (VSCs) yang dihembuskan melalui mulut. Mengidentifikasi napas penderita diabetes mellitus dapat dilakukan dengan menggunakan sensor gas TGS 2602 yang mampu mendeteksi unsur hydrogen sulfida dan MQ 4 https://doi.org/10.25077/jitce.2.02.85-91.2018 yang mampu mendeteksi unsur methane. Hasil deteksi sensor akan diolah untuk merubah sinyal domain waktu menjadi sinyal domain frekuensi melalui Fast Fourier Transform (FFT). Hasil spektrum proses FFT diproses untuk mendapatkan pola data kadar VSCs dari nafas. Hasil pola data ini dijadikan sebagai data input untuk jaringan saraf tiruan sebagai data untuk pengambilan keputusan dengan metode backpropagation.

\section{TINJAUAN PUSTAKA}

\section{Diabetes}

Diabetes mellitus (DM) adalah keadaan abnormal dimana produksi insulin dalam tubuh tidak mencukupi untuk mengubah glukosa (yang dihasilkan karbohidrat) ke dalam bentuk glikogen. Umumnya terdapat 2 tipe diabetes, yaitu diabetes tipe 1 yaitu diabetes yang terjadi karena faktor genetik(keturunan), dan diabetes tipe 2 yaitu diabetes yang terjadi karena pola hidup yang tidak sehat[1]. Prevalensi diabetes mellitus menurut Diabetes Federation (IDF) pada tahun 2006 terdapat 250 juta penduduk dunia tercatat menderita penyakit ini.

Attribution-NonCommercial 4.0 International. Some rights reserved 


\section{Sensor TGS 2602}

Sensor TGS 2602 dari Figaro ini memiliki tingkat sensitivitas dan selektivitas yang baik pada kontaminasi udara terhadap kadar gas di luar ruang seperti ammonia dan $\mathrm{H}_{2} \mathrm{~S}$. Konsentrasi yang rendah dari alkohol. Target gas: $\mathrm{H}_{2} \mathrm{~S}$. karena ukuran chip sensor yang kecil, TGS 2602 hanya membutuhkan arus pada pemanas yang kecil pula yakni sebesar 56mA dan komponen ini distandarisasikan pada paket komponen TO-5. Gambar 1 adalah tampilan fisik dari TGS 2602 dalam paket TO-5.

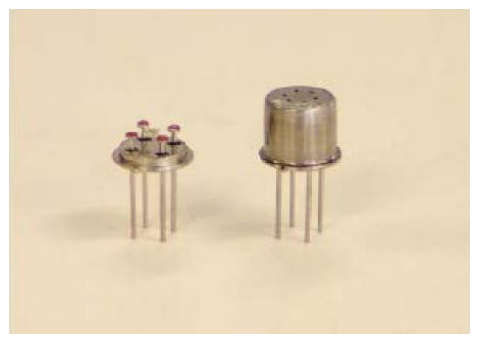

Gambar 1. Sensor TGS 2602

\section{Sensor MQ 4}

Sensor MQ 4 merupakan sensor yang memiliki sensitifitas yang tinggi terhadap gas methane, butane dan propane. Sensor ini tergolong jenis sensor semi konduktor yang memiliki konsentrasi gas $300-10000 \mathrm{ppm}$. Target pada sensor ini adalah gas methane. Gambar 2 merupakan tampilan fisik dari Sensor Gas MQ 4
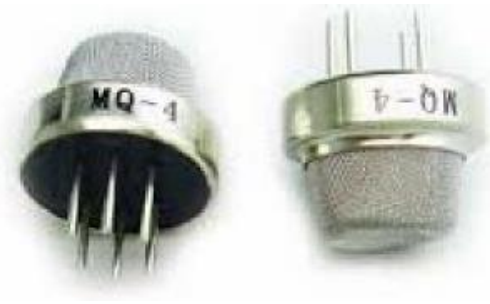

Gambar 2. Sensor Gas MQ 4 syaraf tiruan sama dengan cara kerja manusia yaitu belajar melalui contoh. JST dibentuk untuk memecahkan masalah tertentu seperti pengenalan pola atau klasifikasi karena proses pembelajaran[11].

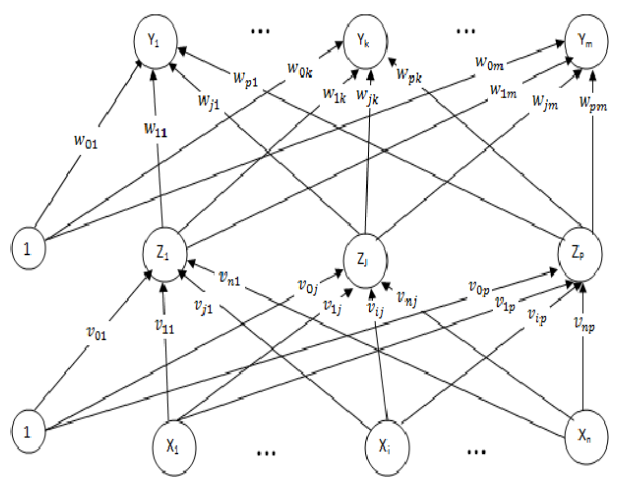

Gambar 3. Struktur Jaringan Syaraf Tiruan

\section{Raspberry Pi}

Raspberry Pi merupakan single board seukuran kartu kredit. Dikarenakan ukurannya yang jauh lebih kecil dari komputer biasa, kemampuan komputer mini ini pun dibawah komputer biasa. Raspberry Pi kebanyakan digunakan untuk kegiatan pembelajaran yang tidak memerlukan alokasi memori yang besar seperti belajar pemrograman[13]. Berkut gambar 2.15 tampilan fisik Raspberry Pi.

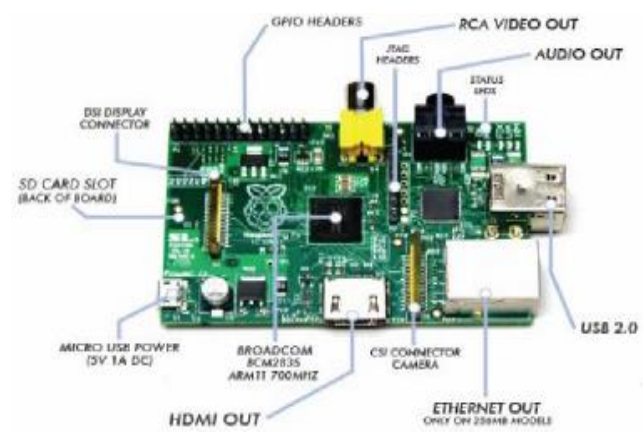

Gambar 4. Raspberry Pi [13]

\section{Arduino Uno}

Ardunio Uno adalah board berbasis mikrokontroler pada ATmega328. Board ini memiliki 14 digital input / output pin (dimana 6 pin dapat digunakan sebagai output PWM), 6 input analog, $16 \mathrm{MHz}$ osilator kristal, koneksi USB, jack listrik tombol reset. Pin-pin ini berisi semua yang diperlukan untuk mendukung mikrokontroler, hanya terhubung ke komputer dengan kabel USB atau sumber tegangan bisa didapat dari adaptor AC-DC atau baterai untuk menggunakannya.

\section{Jaringan Syaraf Tiruan}

Jaringan syaraf tiruan adalah paradigma pengolahan informasi yang terinspirasi oleh syaraf secara biologis, seperti proses informasi pada otak manusia. Cara kerja jaringan 


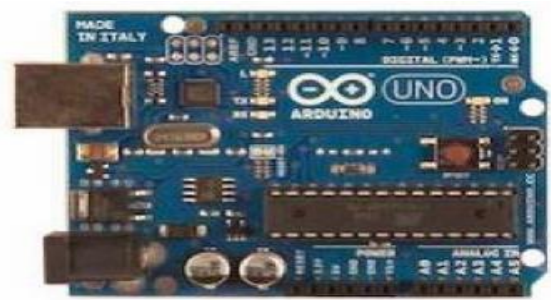

Gambar 5. Papan Arduino [16]

\section{ADC (Analog To Digital Converter)}

ADC adalah pengubah input analog menjadi kode kode digital. ADC banyak digunakan senagai pengatur proses industri, komunikasi digital dan rangkaian pengukuran / pengujian. Umumnya ADC digunakan sebagai perantara antara sensor yang kebanyakan analog dengan sistem komputer seperti sensor suhu, cahaya, tekanan / berat, aliran dan sebagainya kemudian di ukur dengan menggunakan sistem digital (Komputer).

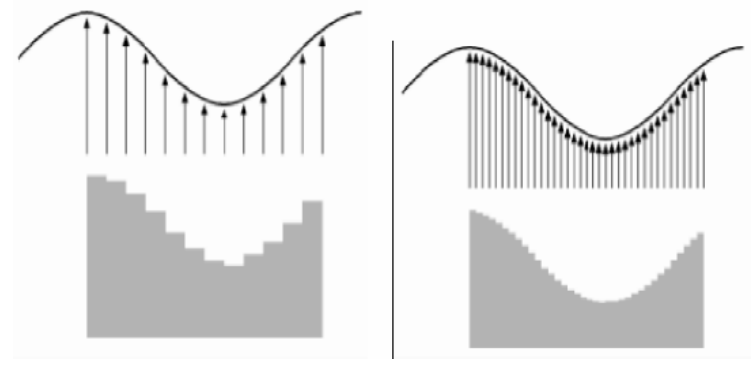

Gambar 6. ACD dengan kecepatan sampling rendah dan sampling tinggi

\section{METODOLOGI}

Berikut adalah rancangan penelitian yang diilustrasikan pada Gambar 7. Langkah awal yang dilakukan dalam peracangan ini dimulai dari perancangan struktur jaringan syaraf tiruan backpropagation, terdapat 8 unit input, 8 unit hidder layer, dan 2 unit output, yang dideskripsikan pada Gambar 8 .

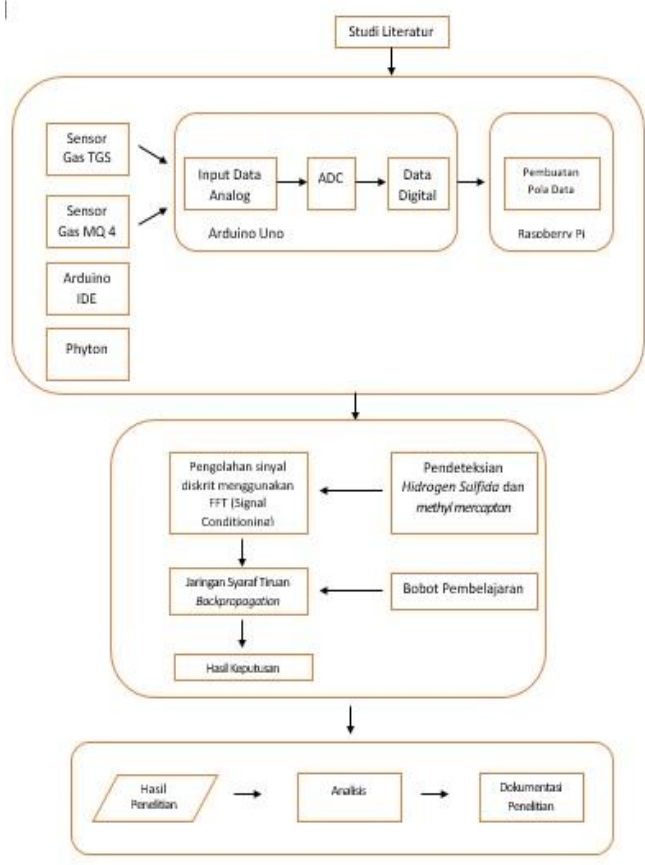

Gambar 7. Rancangan Publikasi

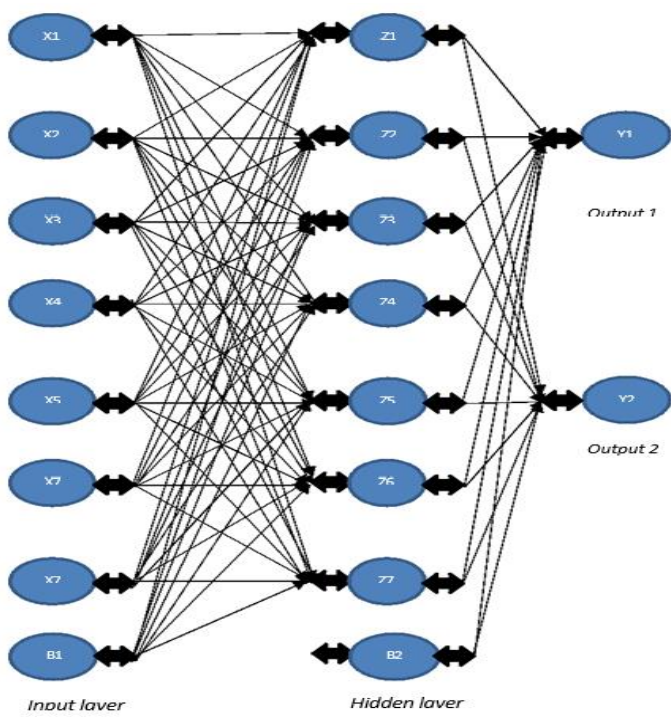

Gambar 8. Rancang Struktur Back Propagation

Setelah perancangan struktur jaringan syaraf tiruan backpropagation selesai, maka langkah perancangan selanjutnya adalah perancangan proses pembelajaran jaringan syaraf tiruan backpropagation, dimana proses pembelajaran tersebut dimulai dari proses training bobot seperti Gambar 9 berikut ini: 


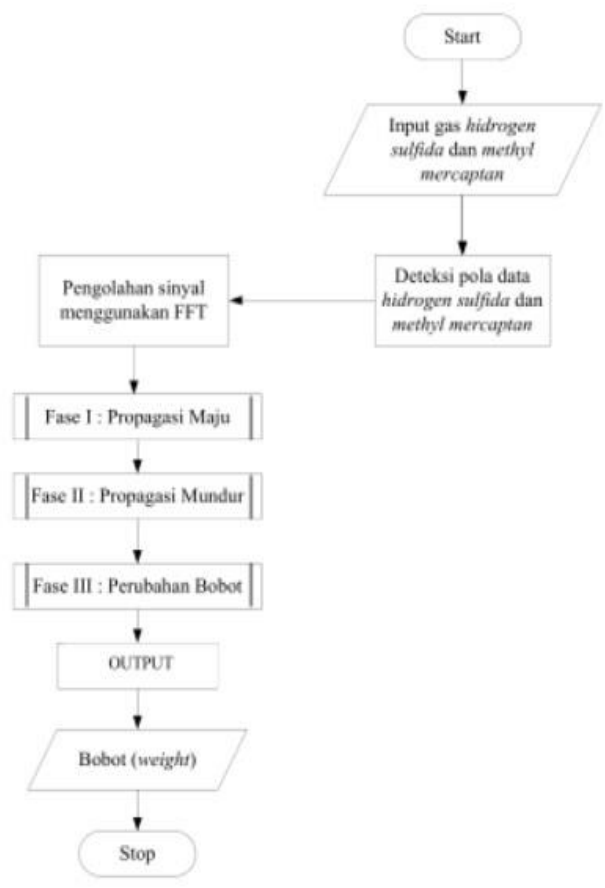

Gambar 9. Rancangan Proses Training Pembelajaran Bobot

\section{HASIL DAN PEMBAHASAN}

Pengambilan pola data terhadap penderita diabetes mellitus menggunakan spektrum counter sampai data ke-32. Sampel yang dideteksi dihembuskan ke dalam selang input dan berada dalam ruangan tertutup, agar sensor dapat membaca data dengan baik. Berikut merupakan gambar spektrum FFT menggunakan counter sampai data ke-32 sampel diabetes mellitus dan sampel acak:

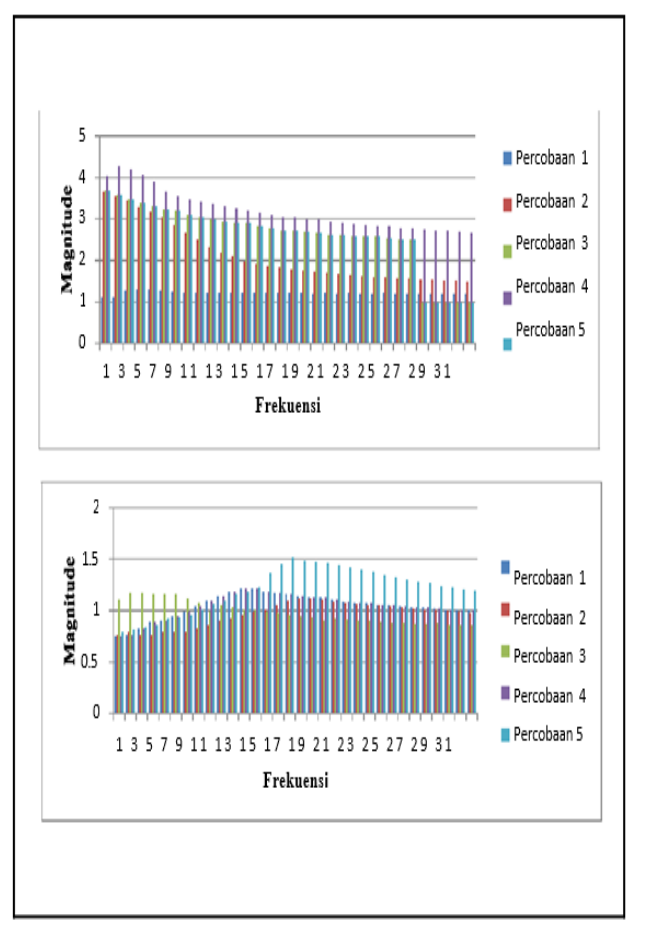

Gambar 10. Spektrum FFT Sensor TGS 2602
Berdasarkan gambar 10, diperoleh bahwa respon sensor terhadap sampel diabetes mellitus dan sampel acak stabil pada frekuensi ke 4 sampau frekuensi ke 20.

Untuk proses identifikasi menggunakan jaringan syaraf tiruan Backpropagation diambil 8 input yang masing masingnya 4 input dari sensor TGS 2602 dan sensor MQ 4, maka frekuensi yang dipakai untuk input jaringan syaraf tiruan pada sensor TGS 2602 adalah frekuensi ke-8 sampai frekuensi ke 11. Sedangkan untuk sensor MQ 4 adalah pada frekuensi ke 4 sampai frekuensi ke 7.

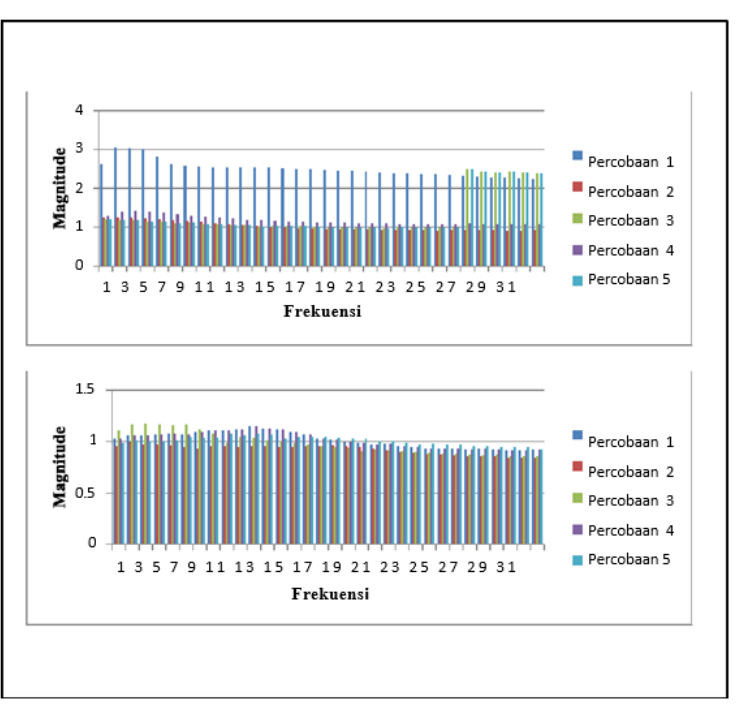

Gambar 11. Spektrum FFT Sensor MQ 4

Nilai FFT yang diambil berdasarkan 5 kali percobaan, dengan mengambil 4 pola data untuk sensor TGS 2602 dan 4 untuk pola data MQ 4. Berikut pola data yang diambil pada sampel diabetes mellitus.

Tabel 1. Nilai Frekuensi Dominan Sensor TGS 2602 dari spektrum FFT Diabetes Mellitus

\begin{tabular}{|c|c|c|c|c|c|}
\hline \multirow{2}{*}{ INPUT } & \multicolumn{5}{|c|}{ MAGNITUDE SPEKTRUM DATA INPUT } \\
& \multicolumn{5}{|c|}{ SAMPEL } \\
\cline { 2 - 6 } & $\mathbf{1}$ & $\mathbf{2}$ & $\mathbf{3}$ & $\mathbf{4}$ & $\mathbf{5}$ \\
\hline $\mathbf{1}$ & 1.223167 & 2.659677 & 3.086364 & 3.470381 & 3.086364 \\
\hline $\mathbf{2}$ & 1.218426 & 2.498485 & 3.043695 & 3.404008 & 3.043695 \\
\hline $\mathbf{3}$ & 1.213685 & 2.323069 & 2.991544 & 3.361339 & 2.991544 \\
\hline $\mathbf{4}$ & 1.208944 & 2.180841 & 2.944135 & 3.31393 & 2.944135 \\
\hline
\end{tabular}

Tabel 1 merupakan hasil nilai magnitude sensor TGS 2602 dari pasien diabetes mellitus dengan 5 kali percobaan. Pada tabel terlihat bahwa nilai dari setiap percobaan berbeda sehingga akan https://doi.org/10.25077/jitce.2.02.85-91.2018 
menentukan hasil dari identifikasi yang akan dilakukan pada metode backpropagation.

Tabel 2 merupakan hasil nilai magnitude sensor MQ 4 dari pasien diabetes mellitus dengan 5 kali percobaan. Pada tabel terlihat bahwa nilai dari setiap percobaan berbeda. Terjadi perubaan yang signifikan antara percobaan 1 dan percobaan berikutnya, hal ini terjadi karena cara penginputan napas yang berbeda.

Tabel 2. Nilai Frekuensi Dominan Sensor MQ 4 dari spektrum FFT Diabetes Mellitus

\begin{tabular}{|c|c|c|c|c|c|c|c|}
\hline No. & Bobot & $\begin{array}{l}\text { Nilai } \\
\text { Bobot }\end{array}$ & Keterangan & No. & Bobot & \begin{tabular}{|c|} 
Nilai \\
Bobot
\end{tabular} & $\begin{array}{c}\text { Keterang } \\
\text { an }\end{array}$ \\
\hline 1 & V11 & -16.0715 & & 49 & V71 & 193.1 & \\
\hline 2 & V12 & -14682.9 & & 50 & V72 & 4.5 & \\
\hline 3 & V13 & 18904.8 & & 51 & V73 & 5589 & \\
\hline 4 & V14 & -123996.0 & Nilai Bobot & 52 & V74 & - & Nilai \\
\hline 5 & V15 & 988.5 & Input ke Z1 & 53 & V75 & $\begin{array}{r}1561 \\
1498 . \\
4\end{array}$ & $\begin{array}{c}\text { Bohot } \\
\text { Input ke } \\
77\end{array}$ \\
\hline 6 & V16 & -1052.6 & & 54 & V76 & 1208. & \\
\hline 7 & V17 & 2325.7 & & 55 & V77 & 527.1 & \\
\hline 8 & V18 & 3233.1 & & 56 & V78 & - & \\
\hline 9 & V21 & -16075.4 & & 57 & V81 & $\begin{array}{r}2301 \\
3871 . \\
9\end{array}$ & \\
\hline 10 & V22 & -3569.9 & & 58 & V82 & 8776. & \\
\hline 11 & V23 & -18408.9 & & 59 & V83 & 3761 & \\
\hline 12 & V24 & -129481.7 & Nilai Bobot & 60 & V84 & $\begin{array}{r}14 \\
5855 \\
65 \\
\end{array}$ & $\begin{array}{c}\text { Nilai } \\
\text { Bohot }\end{array}$ \\
\hline 13 & V25 & 2424.4 & Input ke Z2 & 61 & V85 & - & Input $\mathrm{ke}$ \\
\hline 14 & V26 & 2392.6 & & 62 & V86 & 2186. & \\
\hline 15 & V27 & 1206.4 & & 63 & V87 & & \\
\hline 16 & V28 & 2435.9 & & 64 & V88 & & \\
\hline 17 & V31 & 16288.7 & & 65 & V10 & $\begin{array}{r}2338 \\
163.9 \\
762\end{array}$ & $\begin{array}{c}\text { Nilai } \\
\text { Bobot }\end{array}$ \\
\hline 18 & V32 & 36715.7 & Nilai Bobot & 66 & V20 & $\begin{array}{r}193.0 \\
168 \\
\end{array}$ & $\begin{array}{c}\text { Bias Input } \\
k e\end{array}$ \\
\hline 19 & V33 & -19861.4 & Input ke Z3 & 67 & V30 & $\begin{array}{r}45.68 \\
75 \\
\end{array}$ & $\begin{array}{c}\text { Hidden } \\
\text { Layer }\end{array}$ \\
\hline 20 & V34 & -72298.1 & & 68 & V40 & - & \\
\hline
\end{tabular}

\begin{tabular}{|c|c|c|c|c|c|}
\hline \multirow{3}{*}{ INPUT } & \multicolumn{5}{|c|}{ MAGNITUDE SPEKTRUM DATA INPUT } \\
\cline { 2 - 6 } & $\mathbf{1}$ & $\mathbf{2}$ & $\mathbf{3}$ & $\mathbf{4}$ & $\mathbf{5}$ \\
\hline $\mathbf{1}$ & 3.010508 & 1.23739 & 1.147312 & 1.398583 & 1.147312 \\
\hline $\mathbf{2}$ & 2.806647 & 1.213685 & 1.142571 & 1.370137 & 1.142571 \\
\hline $\mathbf{3}$ & 2.62175 & 1.18998 & 1.099902 & 1.327468 & 1.099902 \\
\hline $\mathbf{4}$ & 2.579081 & 1.156794 & 1.123607 & 1.294282 & 1.123607 \\
\hline
\end{tabular}

Berikut grafik pola data sensor TGS 2602 dan MQ 4 terhadap sampel Diabetes Mellitus dengan 5 kali percobaan :

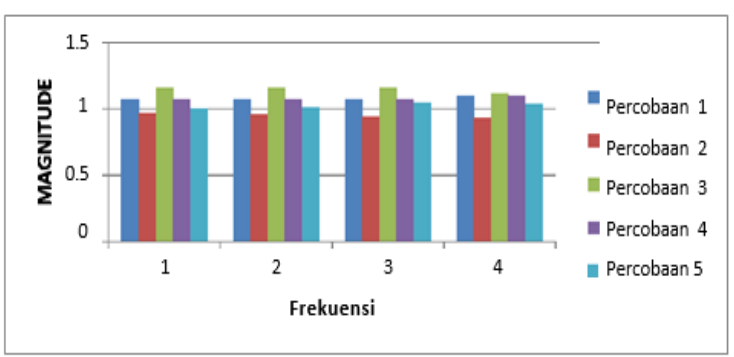

Gambar 12. Pola Data Sensor TGS 2602 terhadap Diabetes Mellitus

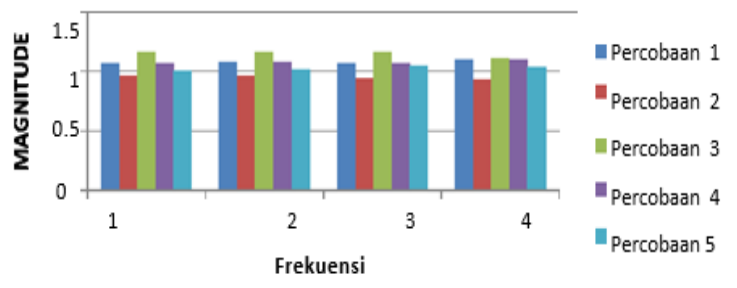

Gambar 13. Pola Data Sensor MQ 4 terhadap Diabetes Mellitus

Proses training menggunakan hasil keluaran FFT dengan 1 sampel data penderita diabetes mellitus dan 1 data sampel tidak menderita diabetes mellitus. Data keluaran FFT ini dijadikan sebagai data input untuk proses training backpropagation. Data yang diambil untuk dijadikan training adalah data pada percobaan 1. Berikut data inputan training backpropagation terlihat pada tabel 3 .

Tabel 3. Sampel Data Training Backpropagation

\begin{tabular}{|c|c|c|c|c|c|c|c|c|}
\hline Sampel & \multicolumn{7}{|c|}{ Input } \\
\cline { 2 - 9 } Data & $\mathrm{X} 1$ & $\mathrm{X} 2$ & $\mathrm{X} 3$ & $\mathrm{X} 4$ & $\mathrm{X} 5$ & $\mathrm{X} 6$ & $\mathrm{X} 7$ & $\mathrm{X} 8$ \\
\hline Diabet & 1.223 & 1.0383 & 1.2184 & 1.0904 & 1.213 & 1.1426 & 1.208 & 1.1852 \\
\hline Tidak & 3.010 & 1.0715 & 2.8066 & 1.0761 & 2.621 & 1.0715 & 2.579 & 1.0951 \\
Diabetes & 5 & & & 9 & 8 & & 1 & \\
\hline
\end{tabular}

Pada tabel 4 dilakukan proses training data dengan menginputkan data yang didapat dari FFT. Data yang diinputkan ini adalah data FFT yang telah ditentukan pola uniknya. Input yang digunakan untuk training backpropagation yaitu 8 input untuk penderita diabetes mellitus dan 8 input untuk tidak diabetes mellitus. Data yang diambil adalah 4 pola data dari sensor TGS 2602 dan data dari sensor MQ 4. Setelah dilakukan training maka akan didapatkan nilai bobot hasil training backpropagation.

Tabel 4. Bobot Hasil Training Backpropagation

\begin{tabular}{|c|c|c|c|c|c|}
\hline 21 & V35 & 2088.6 & 69 & V50 & 150.38 \\
\hline 22 & V36 & 769.6 & 70 & V60 & עلs \\
\hline
\end{tabular}




\begin{tabular}{|c|c|c|c|c|c|c|c|}
\hline 23 & V37 & -1485.1 & & 71 & V70 & 125.21 & \\
\hline 24 & V38 & 556.3 & & 72 & V80 & -1 & \\
\hline 25 & V41 & -22182.7 & \multirow{8}{*}{$\begin{array}{l}\text { Nilai Bobot } \\
\text { Input ke Z4 }\end{array}$} & 73 & W11 & -0.7365 & \multirow{8}{*}{$\begin{array}{c}\text { Bobo } \\
\mathrm{t} \\
\text { Hidde } \\
n \text { ke } \\
\mathrm{Y} 1\end{array}$} \\
\hline 26 & V42 & 2573.6 & & 74 & W12 & 1.4598 & \\
\hline 27 & V43 & 57879.0 & & 75 & W13 & 0.9105 & \\
\hline 28 & V44 & 63964.8 & & 76 & W14 & 0.6983 & \\
\hline 29 & $\mathrm{~V} 45$ & 2219.4 & & 77 & W15 & 2.6540 & \\
\hline 30 & V46 & 230.8 & & 78 & W16 & 2.0744 & \\
\hline 31 & V47 & -1194.5 & & 79 & W17 & -1.2191 & \\
\hline 32 & V48 & 20.0 & & 80 & W18 & -4.0341 & \\
\hline 33 & V51 & 16062.0 & \multirow{8}{*}{$\begin{array}{l}\text { Nilai Bobot } \\
\text { Input ke Z5 }\end{array}$} & 81 & W21 & -1.1621 & \multirow{10}{*}{$\begin{array}{c}\text { Bobo } \\
\mathrm{t} \\
\text { Hidd } \\
\text { en ke } \\
\mathrm{Y} 2\end{array}$} \\
\hline 34 & V52 & 1761.7 & & 82 & W22 & 3.7959 & \\
\hline 35 & V53 & -42569.3 & & 83 & W23 & -7.3111 & \\
\hline 36 & V54 & - & & 84 & W24 & -3.0855 & \\
\hline 37 & V55 & 1720.3 & & 85 & W25 & 1.5028 & \\
\hline 38 & V56 & 1969.5 & & 86 & W26 & 0.1307 & \\
\hline 39 & V57 & 2096.4 & & 87 & W27 & 2.8312 & \\
\hline 40 & V58 & -1514.1 & & 88 & W28 & -1.0657 & \\
\hline 41 & V61 & 11223.8 & \multirow{8}{*}{$\begin{array}{l}\text { Nilai Bobot } \\
\text { Input ke Z6 }\end{array}$} & 89 & W10 & -7.7547 & \\
\hline 42 & V62 & -19674.9 & & 90 & W20 & -0.0222 & \\
\hline 43 & V63 & 49773.7 & & & & & \\
\hline 44 & V64 & 85975.2 & & & & & \\
\hline 45 & V65 & -1459.8 & & & & & \\
\hline 46 & V66 & -39.5 & & & & & \\
\hline 47 & V67 & -3397.6 & & & & & \\
\hline 48 & V68 & 554.5 & & & & & \\
\hline
\end{tabular}

Berikut adalah hasil identifikasi Diabetes Mellitus dengan 5 kali percobaan.

Tabel 5. Hasil Identifikasi

\begin{tabular}{|c|c|c|c|c|}
\hline \multicolumn{2}{|c|}{ No. Input } & \multirow{2}{*}{$\begin{array}{l}\text { Nilai Input } \\
\text { Hasil FFT }\end{array}$} & \multirow{2}{*}{$\begin{array}{l}\text { Output Proses } \\
\text { Identifikasi }\end{array}$} & \multirow{2}{*}{$\begin{array}{c}\text { Hasil } \\
\text { Keputusan }\end{array}$} \\
\hline $\mathbf{U j i}$ & $\mathbf{K e}-$ & & & \\
\hline \multirow[t]{8}{*}{1} & 1 & 1.009824 & \multirow{8}{*}{$\begin{array}{c}\mathrm{Y} 1= \\
\mathrm{Y} 2=4.14359525728 \\
\text { Hasil keputusan : } 0 \\
0\end{array}$} & \multirow{8}{*}{$\begin{array}{l}\text { DIABETES } \\
\text { MELLITUS }\end{array}$} \\
\hline & 2 & 1.005083 & & \\
\hline & 3 & 1.066716 & & \\
\hline & 4 & 1.014565 & & \\
\hline & 5 & 1.099902 & & \\
\hline & 6 & 1.047752 & & \\
\hline & 7 & 1.156794 & & \\
\hline & 8 & 1.03827 & & \\
\hline 2 & 1 & 1.853714565 & $\begin{array}{c}Y 1=0.0190694694 \\
Y 2=\end{array}$ & $\begin{array}{l}\text { DIABETES } \\
\text { MELLITUS }\end{array}$ \\
\hline
\end{tabular}

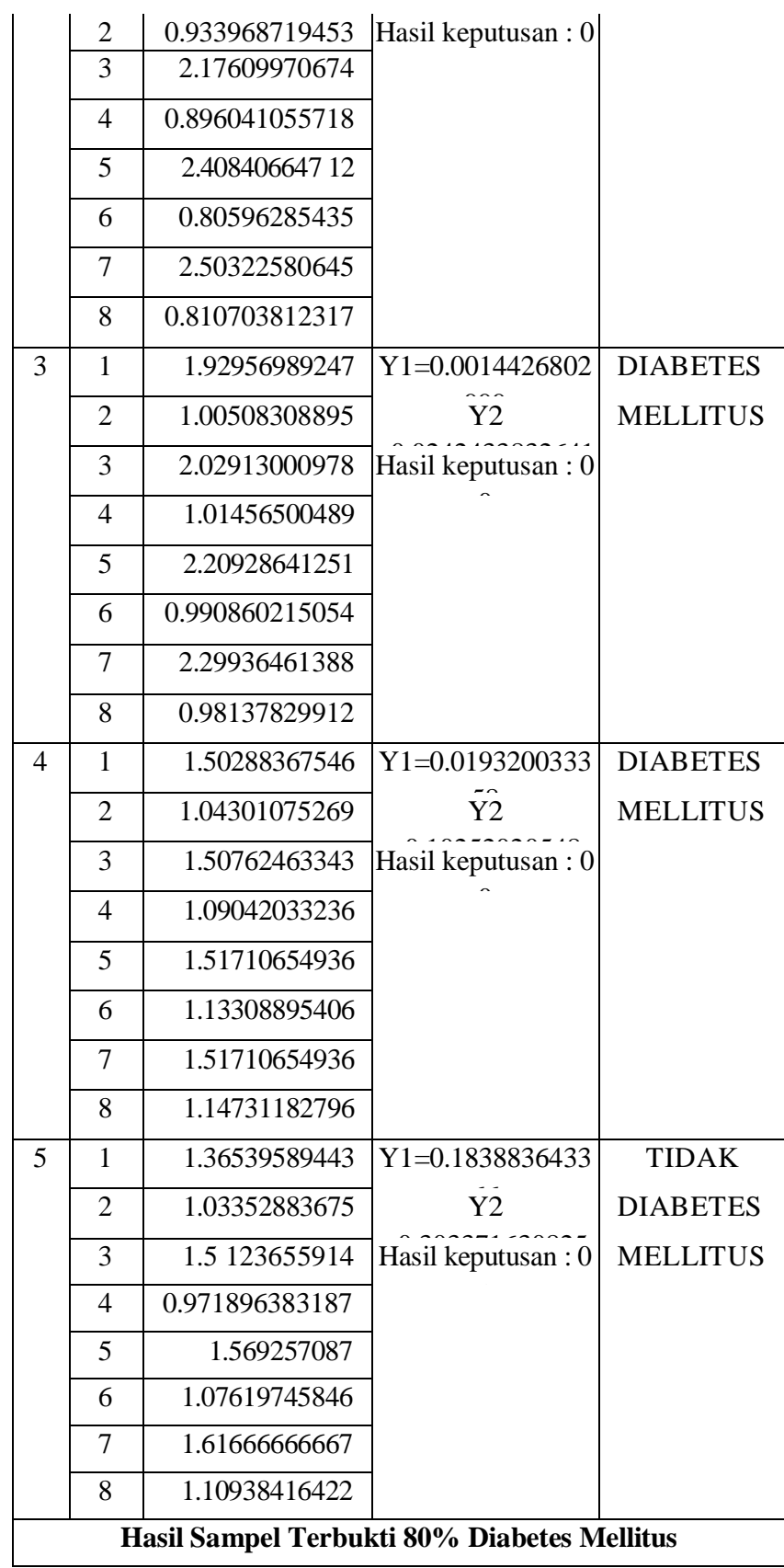

\section{KESIMPULAN}

Dari hasil pengujian yang dilakukan serta analisa identifikasi, maka dapat diambil kesimpulan sebagai berikut :

1. Sensor gas TGS 2602 dapat mengidentifikasi pada gas H2S dan sensor gas MQ 4 dapat mengidentifiaksi gas $\mathrm{CH} 4$ yang ada pada bau napas penderita diabetes mellitus.

2. Pengolahan FFT menggunakan 32 titik menghasilkan pola data, dengan pola data yang didapatkan akan diambil counter yang memiliki nilai yang stabil untuk dijadikan input jaringan syaraf tiruan backpropagation.

3. Nilai magnitude yang berasal dari hasil output metode FFT akan dijadikan inputan jaringan syaraf tiruan, sedangkan

https://doi.org/10.25077/jitce.2.02.85-91.2018 
hasil training backpropagation dapat digunakan untuk identifikasi seseorang penderita penyakit diabetes mellitus.
[16] Ginting, Bernike Natalia. 2012. Penggerak Antena Modem USB Tiga Dimensi Berbasis Mikrokomputer Menggunakan Arduino Uno. Universitas Sumatra Utara, Medan.

[17] A.Y, Ratu, 2013. Identifikasi Kemurnian Solar dengan Sensor Gas Semikonduktor (TGS Figaro) Menggunakan Jaringan Syaraf Tiruan Metode Pembelajaran Backpropagation. Universitas Andalas Sumatra Barat, Padang.

[1] Redfieryheart., Diabetes and Bad Breath - The Truth Behind the Myth, https://redfieryheart.wordpress.com/2011/04/28/diabetes -andbad-breath-the-truth-ehind-the-myth. Diakses tanggal 28 Januari 2015.

[2] A P Deki., Identifikasi Penyakit Halitosis dengan sensor gas menggunakan Jaringan Syaraf Tiruan Metode Pembelajaran Backpropagation., Padang (2014)

[3] Brown, L. A., Williams, A. \& Rogers, B., Title of book, ed. 2, Publisher (1997).

[4] Phillipe (ed), Title of paper, Name of Proc., Publisher (1998).

[5] Anonim. Alat cek Gula Darah http://alatcekguladarah.com di akses tanggal 01 Januari 2015

[6] Anonim Kenali Potensi Diabetes http://www.konimex.com/post/everyday-health-solution diakses tanggal 02 januari 2016

[7] Utami, Endrina 2013. Identifikasi Penyakit Diabetes melalui Bau Urine dengan Sensor Gas menggunakan Metoda Pembelajaran Backpropagation Padang Universitas Andalas

[8] www.perkeni.org

[9] Suprapto In-line Monitoring Senyawa Organik Volatil Pada Limbah Dengan Sensor Gas berbahan Polimer Konduktif Institut Teknologi Sepuluh Nopember, Surabaya

[10] Hendry, Jans. Tanpa tahun. Mengapa Kita Membutuhkan FFT?. https://www.scribd.com/doc/60100313/MengapaKita-Membutuhkan-FFTdan-Contoh-Aplikasinya Diakses tanggal 11 Februari 2014.

[11] Siang ,Jong Jek. 2004. Jaringan Syaraf Tiruan \& Pemogramannya Menggunakan Matlab. Yogyakarta: Penerbit Andi.

[12] DW ,Maharani dan Irawan Afrianto. 2012. Perbandingan Metode Jaringan Syaraf Tiruan Backpropagation dan Learning Vector Quantization pada Pengenalan Wajah . Bandung .

[13] Alee, Ranjam. 2013. Reading Data From a Digital Multimeter Using Raspberry Pi. Turku University Of Applied Sciences.

[14] Maruch, S dan Maruch, A. 2006. Phyton for Dummies. for Dummies, USA.

[15] Demaagd, Kurt., Oliver, Anthony, Oostendorp, Nathan dan Katherine Scott. 2012. Practical Computer Vision With Simple C V. Cambridge University.
[18] Gunardi, Indriyadi, dan Yuniardini S Winiardhani. 2009. Oral Probiotik: Pendekatan Baru Terapi Halitosis (Tinjauan Pustaka). Universitas Indonesia.

[19] www.hwsensor.com, diakses 10 Juni 2015.

[20] Hidayat, Ranu, 2014. Perancangan dan Pembuatan Sistem Deteksi Penyakit Liver, Ginjal dan Dehidrasi Melalui Urin Berbasis Sensor Warna. Universitas Andalas. Sumatra Barat. 